\title{
TELEPÜLÉSRENDSZERÜNK FEJLŐDÉSÉNEK TENDENCIÁI ${ }^{1}$
}

\section{KŐSZEGFALVI GYÖRGY}

A rendszerváltás nyomán és kővetkezményeként alapvetően megváltoztak és változnak a településrendszer fejlödésének feltételei is. Új hatótényezők érvényesưlnek a telepưlésrendszer, s ennek keretében az egyes települések fejlödésében. A változások hatása nemcsak az ország térszerkezetében, a termelés és a különféle szolgáltatások területi elhelyezkedésében, hanem a telepưlésrendszerben és struktúráiban is nyomon követhetö.

Tanulmányunkban azt vizsgáljuk, hogy nagyobb távú kitekintésben a telepưlésrendszer átalakulásának, fejlödésének milyen tendenciáival lehet számolni. Vizsgálatunk alapvetően a településrendszer várható strukturális változásával foglalkozik: a településrendszer szerkezetének - város-falu hálózat - átalakulása, új telepưlés-struktúrák megjelenése és fejlödése következményeiben milyen változásokhoz vezethet a térszerkezetben, a népesség települési viszonyaiban.

A településrendszer strukturáiis változásának markáns szintereként a föváros és térsége, a felgyorsuló és dinamikus gazdasági fejlödés által leginkább érintett régiók nagy- és kőzépvárosai, valamint térségeik, $\mathrm{s}$ a fö kőzlekedési vonalak mentén fekvő telepưlések nevezhetök meg. Ezek a változások az ország térségét feltehetően aránytalanul és egyenlötlenül érintik majd. A területi fejlödés aránytalanságai a településrendszert és annak struktúráit is aránytalanul, egyenlötlenül érintik, sok helyütt - valószínüsíthetően - kedvezőtlen, negativ folyamatokat válthatnak/váltanak ki az ott élö népesség telepulési és ellátottsági viszonyaiban, a munkaalkalmakhoz való hozzájutás feltételeiben. Ez egyenes következménye a településrendszer öntörvénylú fejlödésének, annak hatásaként érvényesül. A következmények érdemleges korrigálására az államnak, illetve a központi irányítás szerveinek csak kevés a lehetőségưk. Az önkormányzatiság viszonyai között végbemenő telepưlésfejlödés, lényegében "magára utalt": az egyes telepúléseknek maguknak kell megteremteniük, biztosítaniuk kedvezőbb irányú, gyorsabb fejlődésük feltételeit, föként biztosítani a fejlesztés szükséges eszkőzeit, ösztönözni a lakosság, a vállalkozások, a kưlönféle helyi szervezetek, civil szerveződések összefogását, konkrét fejlesztési célok érdekében kívánatos összefogását, közös cselekvését.

A telepưlésrendszer helyzetét, fejlỏdésének várható folyamatait vizsgáló, feitáró kutatások sok segítséget jelenthetnek az egyes településeknek is. A kutatások átfogó és sokoldalú elemzéseket, objektív értékítéletet adhatnak az egyes telepưlések, településcsoportok nelyzetéröl, adottságairol, bemutathatják rövidebb-hosszabb távú fejlesztésük lehetőségeit, netán korlátait. Ezen vizsgálatok, értékelések birtokában az egyes települések önkormányzatai maguk alakítják ki fejlesztési stratégiájukat, dolgoznak ki akcióprogramokat adottságaik, potenciális lehetőségeik minél teljesebb körü hasznosítása érdekében. Ennek során döntö szerepe van/lehet a telepưlések kölcsönös érdekeltségén és érdekeken alapuló összefogásának, társulásainak, a kisebb-nagyobb térségeket átfogó településközi, regionális szerveződéseiknek, szővetségeiknek. 
Tanulmányunk alapjául szolgáló kutatásaink során részletesen elemeztük a településrendszer és egyes struktúráinak helyzetét a kilencvenes évek első felében. A fejlődés várható tendenciáinak vizsgálatakor az adottságok számbavétele mellett, tanulmányoztuk más fejlett/fejlettebb országok - dőntően kutatási anyagok, szakirodalmi források alapján, nem nélkủlözve az utazások nyújtotta lehetőségeket sem - településfejlődési folyamatait, a településrendszerek strukturális átalakulását, annak sajátosságait, az azokból levonható kővetkeztetéseket, tanulságokat.

A tanulmány szerzője - végzettségét tekintve - városrendező mérnők: tőbb mint négy évtizedes szakmai-tudományos tevékenysége a településtudomány területéhez füződött/füződik. Szemléletét, szakmai megközelítésének alapjait a komplex urbanisztikai felfogás határozza meg. Ezt azért tartja szükségesnek kiemelni, hogy az olvasók a tanulmányban megállapításait, kővetkeztetéseit ennek megfelelően érielmezzék, értékeljék.

\section{Budapest térsége településrendjének várható fejlődése, átalakulása}

A rendszerváltás óta eltelt években végbement terület- és telepủlésfejlödési folyamatok nyomán valószínűsíthető az a következtetés, hogy a településviszonyok legmarkánsabb strukturális átrendezỏdésével a jövóben is Budapest térségében lehet számolni. A föváros agglomerációjának (a ma is érvényes korábbi lehatárolás alapján) fejlődésében különféle folyamatok együttes hatása érvényesül. Az ország népességszáma csökken, az agglomeráció településeinek többségében ugyanakkor gyarapodik. Az érintett telepủlések népességgyarapodása több forrásból táplálkozik: a főváros területéról kitelepülőkből, az ország más térségeiből ide bevándorlókból és a hazánkban letelepedỏ külföldiek egy részéből, akik lakóhelyỉket e települések kőzưl választják. A népességgyarapodás nyomán jelentős volumenủ lakásépítés valósult és valósul meg. A lakásépítés ősztơnzőleg hat, elösegíti a települések alapinfrastruktúrájának, a lakosság infrastrukturális ellátottsági viszonyainak számokban is jól nyomon követhető fejlődését, korszerüsödését. Ez egyaránt megfigyelhető a vonalas és intézményi infrastruktúra vonatkozásában. A fóvárossal agglomerálódó terület már régen túllépte az egykor központi határozattal rögzített - 43 telepủlésből álló - agglomeráció határait. A pozitív demográfiai folyamatok kiváltotta, ösztőnözte agglomerációs fejlödés a fỏváros közvetlen térségében a településrend alakulásának döntő tényezője.

A budapesti agglomeráció erőteljes fejlődésével és területi növekedésével számolhatunk az elkövetkezó évtizedekben is. Hazánk az urbanizációs fejjödés olyan szakaszába jut, amikor felgyorsul és markánsan kirajzolódik a telepưlésrendszer strukturális átalakulásának meghatározó jegyeként a szuburbiák gyors nővekedése. Országon belül ennek a fejlödésnek a legszembetünöbio színtere minden valószínủséggel - a budapesti agglomeráció (a mainál lényegesen nagyobb kiterjedésben) térsége lesz. Ma még a népesség ki-, illetve odatelepülése a fejlődés egyik döntő hatótényezője. A fővárosból kivezető föutak mentén megvalósult/megvalósuló zöldmezős beruházások már ma is jelentős szerepet játszanak az agglomerációs fejlödésben. A jövőben várhatóan a felgyorsuló zőldmezós beruházások tovább erôsftik az agglomeráció és a fóváros sokirányú kapcsolatait, s ma a budapesti térség peremén, vagy attól távolabb fekvő́ városokat 
is bevonják/bevonhatják a szuburbán fejlődés folyamatába. Budapest körül az agglomerálódási folyamatok erőteljes érvényesülésének eredményeként nagyobb kiterjedésủ városrégió kialakulásával számolhatunk.

Ebben a várható folyamatban meghatározó szerepe lehet a föváros körül elhelyezkedỏ belső és kưlső városgyürünek. A föváros közvetlen szomszédságában fekvő - a korábbi döntés alapján még nem a budapesti agglomerációhoz sorolt városokat az elmúlt években felgyorsult fejlödést jelzó térség agglomerálja: az összefüggő településtest magához "kapcsolja". Ezen városok között említhetjük többek között Vácot, Gödöllöt, Monort. Ebben a folyamatban döntő szerepe van/lehet a közlekedési infrastruktúra rendszereinek (vasút és közút hálózatnak). Ez a körülmény valószinủsiti azon feltételezésünket, hogy az agglomerálódás várható folyamatai Budapest távolabbi vonzásában fekvő térségekben is csápszerúen, vagyis markánsan a fö közlekedési vonalak mentén bontakoznak ki. Ez területi és települési aránytalanságokat hozhat magával az agglomerálódás által érintett térségben: intenzíven/intenzivebben összefonódó térségek váltakoznak majd olyan "árnyékterületekkel", melyekben az agglomerálódás szignifikáns jegyei népességgyarapodás, jelentősebb lakásépítés, helyi infrastruktúra fejlődése és korszerủsödése, urbanizáltabb területhasznosítás stb. - kevéssé figyelhetők meg. A fövárosba vezetö, illetve onnan kifelé irányuló fó közlekedési vonalak mentén fekvő területek, települések felgyorsuló agglomerálódása a Budapest körüli belsö városgyürủ térségeiben is felerősíti/felerösítheti ezen városok és a közvetlen szomszédságukban elhelyezkedỏ községek területi összefonódását, összenövését, összefüggö településtest kialakulását.

A fôváros köruuli térstruktúra nagymérvü átalakulásával, a területi, településközi kapcsolatok átrendeződésével lehet számolni. Ebben a folyamatban - a fentiekben már emlitetteken kívull - más tényezök hatása is érvényesullhet/érvényesül. Az agglomerálódásból fakadóan kínálkozó lehetőségek kihasználására szerveződő zöldmezős beruházások e folyamat eröteljes ösztönzői lehetnek. Az infrastruktúra rendszerek eröteljes fejlödése, kiépülése döntô tényezóként említhető az agglomerálódás térformáló, a térkapcsolatokat átrendezö szerepének érvényesưlésében. Az infrastruktúra szerepe, jelentősége az agglomerálódási folyamatokaban kettős jellegü. A közlekedési infrastruktúra rendszerei; kiváltói, ösztönzỏi az érintett térségekben várhatóan végbemenö folyamatoknak. Az infrastruktúra más rendszerei - mintegy követő jelleggel - tovább erōsitik, teljessé teszik az új telepũlésstruktúra - adott esetben az agglomeráció - fejlődését, összefüggö településtestkénti szerveződését (a közmüves víz, energiaellátás, csatornázás hálózatai, a közintézmények rendszerei stb.). A lakásépítések, mint a települési infrastruktúra egyik legjelentösebb összetevője, egyrészt kiváltják, ösztönzik az agglomerálódás folyamatát, az összefüggö településtest kiterjeszkedését eredményezik/eredményezhetik. Az infrastruktúra követö jellegủ elemeinek kiépülése újabb ösztönzést ad/adhat a lakásépítési akciók megvalósításához.

Az agglomerálódás emlitett folyamatai kínálta lehetöségek, jelentős előnyök hasznosítása csak az érintett térségek településeinek - kölcsönös érdekeik felismerésén alapuló - együttmüködése, összefogása, társulása révén mehet végbe, valósulhat meg. A települési önkormányzatiság müködésének eddigi tapasztalatai e 
vonatkozásban még viszonylag csekély eredménnyel szolgálnak. $\mathrm{Az}$ idő elörehaladtával e tapasztalatok, a települések kölcsőnös érdeklődésũ és érdekú társulásának elönyei (pl. az infrastruktúra koordinált fejlesztésében) és esetleges hátrányai (a környezet terhelésének nem kívánatos növekedésében) szélesebb körú érvényesưlésének, megnyilvánulásának adnak majd teret. A telepưlési ơnkormányzatok magasabb színvonalú mükődésének egyik alapvető feltételét a telepưlésközi együttmúkődést kifejezỏ társulások szélesebb körü elterjedése, müködése segíti/segítheti elö. Ez a körülmény is indokolja, hogy a települési ơnkormányzatok tevékenységében a nagyobb távú kitekintésen alapuló szemlélet, felfogás a jövőben markánsabban nyilvánuljon meg.

$\mathrm{Az}$ agglomerálódási folyamat várható felgyorsulása, $\mathrm{s}$ ennek hatására a fơváros térségében kialakult agglomeráció területének jelentós kiterjeszkedése alapjaiban ủj feltételeket jelenthet a kủlső városgyürü fejlödése számára is (Esztergom, Tatabánya, Székesfehérvár, Dunaújváros, Kecskemét, Szolnok, Salgótarján). A jövöbeni fejlödés várható tendenciáit vizsgálva, az a következtetés fogalmazható meg, hogy a külsó városgyürü által lehatárolt térségben nagy városrégió kialakulásával számolhatunk. Ezt a folyamatot a vonalas infrastruktúra rendszerek országon belüli nagymérvư Budapest térségi koncentrálódása a jövőben is erősíti (pontosabban tovább erősíti). A közlekedési infrastruktúra rendszereinek eme koncentrálódását mérsékló akciók eddig még sorra-rendre megrekedtek az elméleti felvetések és az esetenkénti tervezési javaslat szintjén. Az agglomerálódás elmélyülése és földrajzi kiterjeszkedése a föváros közvetlen vonzáskörzetében mindenképpen erősíti a városrégió - igaz hosszabb időtávra valószínüsíthetỏen kialakulásának, fejlödésének folyamatát.

A magyarországi terulet- és telepullésfejlődés egyik legnagyobb kihívásaként a fentiekben említett témát nevezhetjük meg. Korábbi tanulmányainkban (Területi Statisztika, ill. JPTE, Pécs) részletesebben bemutattuk Budapest országon belüli központ szerepének újbóli eröteljes érvényesülését a rendszerváltás óta eltelt években. Ennek továbbgyürüzö hatása, kơvetkezményei ebben a kettős térségi vetületben - agglomeráció és városrégió - figyelhetök meg. Mindezek - a kilencvenes években eddig végbement fejlödési folyamatok, a várható tendenciák indokolják, hogy a térség problémái nagyobb hangsúlyt kapjanak, s ennek megfelelöen kiemelt kutatási témaként szerepeljenek. Az önkormányzatok közötti egyưttmúkỏdés, a központi hatalom szervei és az önkormányzatok egyưttgondolkodásának és cselekvésének alapvetően új formáira és módszereire, fórumaira van/lenne szưkség a várható folyamatok sokoldalú megfigyelése, a szuikséges beavatkozás vizsgálata, majd fokozatos megteremtése érdekében. A budapesti térség tanulmányozása arra hívja fel a figyelmünket, hogy a területi és telepưlési problémák kezelésének teljesen új alapú megközelítésére van sziikség, nemcsak az országon belül, hanem a közép-európai térség regionális egyulttmúkỏdését illetően is.

A fơváros szúkebb-távolabbi vonzáskörzetében eddig végbement, és a jövőben várhatóan kibontakozó folyamatok hatása erőteljes ösztönzést adhat a Duna-menti térség telepulésrendszerének strukturális átrendeződéséhez, a kialakulásban lévó telepưlésstruktúrák fejlődéséhez. Ebben a térségben jelentős agglomerálódás figyelhető meg Györ város körül, valamint az Esztergom-Komárom közőtt 
elhelyezkedő településlánc mentén. A folyamat felerösödését, elmélyưlését valószínűsíthetjük a jövớt illetően. A térséghez közel fekvő, szomszédos Bécsimedencében nagy területi kiterjedésú agglomeráció alakult ki: a települési viszonyok ilyen jellegủ és irányú átalakulása a múlt század utolsó évtizedeiben bontakozott ki, majd az azóta eltelt időszak során különbözó hatótényezök (földrajzi adottságok, ipar, kereskedelem, idegenforgalom fejlödése) egyiuttes következményei érvényesültek az agglomerálódás folyamatában. Pozsony térségében az ötvenes évektől bontakozott ki markánsabban s szlovák fóváros és a szomszédságában fekvő települések közötti területi összefonódás, összefưggő településstruktúra fejlödése (a város népességszáma gyorsan és nagymértékben gyarapodott, a tömeges lakásépités akcióterületei a város külsỏ kerületei és a szomszédos települések voltak).

A nyugat-európai térségben végbement/végbemenỏ agglomerálódási folyamatok jellegét, irányultságát, mozgató erőit vizsgálva, megfogalmazható következtetés, hogy e három - bécsi, pozsonyi, budapesti - egymáshoz viszonylag közeli fơldrajzi elhelyezkedésủ településstruktúra egymás fejlödését ösztönzö, felerösítỏ szerepe az elkövetkező évtizedekben szembetünően érvényesülhet. Feltételezhetö, hogy a nyugat-európai "banán-alakzatú" telepủlésfejlódés a Duna-mente eme térségében is megjelenhet és a településrendszer strukturális átrendezódését, átalakulását eredményezi. Ebben a folyamatban különféle tényezök egyưttesen érvényesülö hatásával lehet számolni: az új kihivásokhoz alkalmazkodó gazdasági átalakulás, az országok közötti munkamegosztás felgyorsuló intenziv fejlődése, elmélyủlése, a sokoldalú és sokirányú kereskedelmi kapcsolatok nagymérvủ dinamizálódása, s nem utolsósorban a vonalas infrastruktúra rendszerek már ma is viszonylag magas szintü fejlettsége - meghatározóan a közlekedési infrastruktúra rendszerek vonatkozásában.

\section{A magyarországi településrendszer szerkezetének várható fejlôdése, átalakulása}

A magyarországi településrendszer szerkezetében az ötvenes évektől figyelhetünk meg számottevỏ és mélyreható változásokat. Az eröltetett ütemü iparosítás nyomăn jelentős népességvándorlás bontakozott $\mathrm{ki}$ az országon belül. Ennek hatására felgyorsult az iparfejlesztés, az ipartelepitések térségeiben - döntően az ún. "ipari tengely" mentén - fekvö városok népességszámának gyarapodása. Különösen gyors volt a föváros népességszámának növekedése. A mezőgazdaság erőszakos átszervezésének, a termelöszövetkezetek létrehozásånak követkrezményeként a hatvanas évek elejétől jeientős tömegek hagyták el falusi, tanyasi gazdaságaikat, vándoroltak a városokba. Elöször a munkaalkalom reményében, majd ennek birtokában lakóhelyuukként is a várost választották. A tömeges lakásépítés technikai bázisának megteremtése a lakásépités jelentős mennyiségi növekedését eredményezte a fóvárosban, a nagyvárosokban, a megyeszékhelyeken és az ipar centrumaiban. Nem olyan mennyiségben azonban, hogy a városokba beáramló, ott munkát vállalókat teljes körúen lakáshoz juttathatták volna. A fövárosban és más nagyvárosokban, megyeszékhelyeken munkát vállalók egy jelentős része ennél fogva a városok közvetlen szomszédságában fekvő községekben telepedett le, ott épített lakást maga és családja számára. A statisztikai megfigyelések a hatvanas évektől jelezték, hogy sok helyütt felgyorsult a városközeli települések 
népességszám gyarapodása. A népességszám gyarapodása, a jelentős lakásépítés kényszerítő erővel hatott a helyi infrastruktúra fejlödésére, kiépülésére (közlekedési kapcsolatok, közmüves víz, illetve vezetékes gázellátás vonatkozásában). A városokból a szomszédos telepủlésekre kitelepülö, illetve azokban újonnan létesített kereskedelmi, raktári létesítmények, különféle kommunális szervezetek új munkahelyeket teremtettek. Mindez összességében a városok és a közvetlen szomszédságukban fekvő települések közötti intenzív jellegü kapcsolatokat erősítette, elmélyítette.

A városok és a közvetlen szomszédságukban fekvő települések nemcsak funkcionális kapcsolatok sokasága révén, hanem teruletileg is összefonódtak egymással, összefüggő településtestek alakultak ki. Az intenzív településfejlödés térségeiben kialakult településtestek a településstruktúrák különbözö típusaiba sorolhatók. Budapest körül - mint arról az elöbbi fejezetben szóltunk - nagy fơldrajzi kiterjeszkedésủ agglomeráció alakult ki. Lényegében száz év erőteljes ipari fejlödése és az általa ösztönzött nagyarányú népesség-koncentráció következményeként agglomeráció fejlődőtt Miskolc térségében, a Sajó-völgyében is. Az agglomerálódás folyamatának felerősödése az ország több helyén eltéró fơldrajzi nagyságú, kiterjeszkedésú agglomerálódó térségek kialakulásához, fejlödéséhez vezetett: a Zagyva-vőlgyében a Salgótarjáni-medencében, Szombathely-Köszeg térségében, a Duna-mentén Esztergom és Komárom között, Pécs és Győr városok közvetlen vonzáskörzetében. Az agglomerálódás sajátos jegyei figyelhetők meg Debrecen, Nyíregyháza, Szeged, Kecskemét városok körül, melyet inkább a szuburbánus fejlődés példáinak lehet tekinteni. Intenzív funkcionális kapcsolatok mellett az anyavárosok és a közvetlen szomszédságukban fekvő telepúlések között lazább területi összefonódás ment/megy végbe. Ebben a sajátos telepủlésfejlödési folyamatban meghatározó szerepe van a történelmileg kialakult és ma is jól nyomon követhető mezőváros-tanyák kapcsolatának. Az egykori város köruli "kertségek" beépülnek, a város vonalas infrastruktúrája "utoléri" ezen teruleteket. Az agglomeráció egy sajátos példáját jeleníti meg a Balaton-térségében kialakult, ủdülési jellegủ agglomeráció.

A megyeszékhelyek, ipari centrumok, a középvárosok körül az intenzív funkcionális kapcsolatok még nem vezettek intenzív területi összefonódásra, összefúggő telepủléstest kialakulására az anyavárosok és a közvetlen szomszédságukban fekvő telepúlések között. Az agglomerálódásnak mintegy kibontakozó szakaszára jellemzően különböző nagyságú, földrajzi kiterjeszkedésủ, egymáshoz még viszonylag lazăn kapcsolódó településcsoportok kialakulása, fejlődése figyelhető meg ezekben a térségekben. A városok kỏrüli agglomerálódást, településcsoportok kialakulását ösztönzik, erősítik a múltbeli magyarországi településfejlődés sajátos adottságai a "várospárok", "városhármasok" (pl. Kecskemét-Nagykörös-Cegléd történelmileg kialakuló városegyüttes, a Középbékési telepủléshalmaz, Tatabánya-Tata-Oroszlány városhármas stb.)

A rendszerváltás utáni években végbement/végbemenỏ változások, társadalmigazdasági átalakulás sok vonatkozásban - pozitív és negatív értelemben egyaránt érinti a településrendszer szerkezetét, a kialakult településstruktúrák helyzetét, fejlödésủk feltételeit. Az ipar korábbi meghatározó szerepe a településrendszer fejlödésében, strukturális átalakulásában nagymértékben háttérbe szorult. 
A településstruktúrák helyzetét, fejlődését ủj hatótényezỏk befolyásolják. Ezek szerepe ma még csak kismértékben érvényesưll. Gondos számbavételük, hatásuk várható következményeinek tanulmảnyozása mindenképpen indokolt és szưikséges.

$\mathrm{Az}$ ipar bázisán kialakult agglomerációk, agglomerálódó térségek - a miskolci, a Zagyva-völgyi, a közép-dunántúli, a tatabányai - helyzete ma a legkedvezötlenebb: a korábban múködött ipari üzemek, üzemcsoportok nagyobb része mára megszünt. Ezekben a térségekben az anyavárosba ingázók nagy része ennek következtében munkahelyét elvesztette. Magas munkanélküliség, az ott élök elszegényedése jellemzi ezen struktúrák mai helyzetét. Az anyavárosból a megélhetés elviselhetetlen terhei miatt mind tơbben az agglomeráció, agglomerálódó térség településeibe költơznek: eladják egykoron az államtól, tanácstól kapott - az ơnkormányzattól értéken alul megvásárolt - lakásaikat. Ez további tehertételként nehezedik az agglomerációk telepuléseire is. A szociális gondok, feszulltségek felhalmozódnak. $\mathrm{Az}$ anyavárosok feszulltségforrásai; a foglalkoztatás, az ellátás, a szociális problémák, s nem utolsósorban a környezetvédelem vonatkozásában a vonzástérségre is kiterjednek, az azokban fekvő települések pozícioit negativan, kedvezötlenul érintik.

Ez nagy kihívás, ami ma a telepulésrendszerünkben jelentkezik, $s$ azonnali beavatkozásokat igényel/igényelne. Ma még nagyon nehezen bontakozik ki az érintett települések ősszefogása, súlyos gondjaik kőzös érdekü és érdekeltségü mérséklése, érdembeni kezelése érdekében. Az állami segítségnyújtás mozgástere mint már említettuk - igen szük. A terület- és településpolitika egyik kiemelt fontosságú feladata a strukturális válság által súlyosan érintett, korábban az iparfejlödés folyamán gyorsan agglomerálódott térségek problémáira a megfelelö kezelés módszereinek kidolgozása és alkalmazása. Ez egyaránt érinti a munkaerỏ átés továbbképzésének, az infrastruktưra kiépítésének és fejlesztésének - föként korszerüsítésének - az új beruházások fogadási feltételei megteremtésének bonyolult feladatait. Ez nemcsak pénz kérdése. Igaz ez a legdöntőbb feltétele a nehéz helyzet megfelelö kezelésének.

Olyan modell kidolgozására és széleskörü alkalmazására lenne szilkség, mely érdemben osztönözhetné, segithetné ezen térségek településeinek önkormányzatait az érdemi összefogásra, társulásra. Nemcsak a mai kedvezötlen, nehéz helyzetből fakadó tennivalok teszik szükségessé a települési onkormányzatok osszehangolt akcióit. A gazdaság remélt fejlödése, dinamizálódása nyomán e térségek is a fejlesztések, a zöldmezős beruházások akcióterületei lehetnek. Ezeknek a településstruktúráknak az általuk kínálta adottságok, lehetőségek hasznosítására fel kell készullniük, fokozatosan megteremtve a fogadás megfelelö feltételeit.

A hazai telepullésrendszer strukturális átalakulásának jövőbeli tendenciáit vizsgálva, megfogalmazható következtetés, hogy a ma válságtérségekben fekvő településstruktúrákkal is számolni kell, a települési szerkezet meghatározói. Helyzetuket, pozíciójukat nagyon kedvezőtlenül, negatívan befolyásoljảk a gazdaság, $\mathrm{s}$ nyomában az elmaradó, nem kielégító szinvonalú infrastruktúrafejlódés, -korszerüsődés következményei. Környezetük állapota - a korábbi évtizedek káros, szennyező folyamatainak kővetkezményeként - igen kedvezőtlen. Ha kialakulnak és a szükséges mértékben érvényesülnek a regionális társadalmi-gazdasági fejlödés új, dinamikus hatótényezői, úgy az említett településstruktúrák szerepe nagyobb távon ismét meghatározó lehet az ország településrendszerében. 
Az ország gazdaságilag, illetve a gazdasági fejlődés feltételeit illetón kiegyensúlyozott, kiegyensúlyozottabb, konszolidáltabb térségeiben a telepưlésrendszer szerkezetének átalakulásával, a korábban kialakult telepủlésstruktúrák továbbfejlődésével számolhatunk a jövöben. A kialakult agglomerálódó térségekben fekvő telepưlések közötti funkcionális kapcsolatok elmélyưlnek, sokoldalúak és intenzív jellegủek lesznek. Ennek eredményeként felerösödik a telepưlések összefonódása, az agglomerálódás korábban kibontakozott folyamatai perfektuálódnak ( $\mathrm{pl}$. Szombathely-Köszeg térségében, a Duna felsõ szakaszán, a dunántúli nagyvárosok - Pécs, Györ - közvetlen vonzásövezetében). A foglalkoztatási gondok mérséklésére, érdembeni kezelésére irányuló akciók, az infrastruktúra fejlesztések koordinálása, a beruházások-befektetések megnyeréséért folytatott piaci harc "összehozza" ezen térségek településeit. Igaz, helyenként ezzel ellentétes tendenciák, az összefogás helyett az elkülöntulés is érvényesülhet.

$\mathrm{Az}$ anyavárosok lakossága ezekben a térségekben is gyarapodó mértékben a kitelepulést, illetve a bevándorlók esetében a városon kívuli letelepedést részesíti majd elönyben. Ennek alapvetöen két oka van: egyrészt a magas lakásépitési költségek a városokban, illetve - állandóan emelkedö tendenciaként - a magas megélhetési költségek, másrészt a városi környezet állapotának gyorsabb szennyeződése és nagyobb mérvul károsodása, a kőzségek kínálta kedvezőbb kömyezeti-fôldrajzi feltételek.

Azokban a térségekben, ahol a funkcionális kapcsolatok és ennek nyomán a területi ősszefonódás az anyavárosok és szomszédságuk települései kőrül várhatóan bontakoznak ki olyan intenzív jelleggel, mint az agglomerációkban, szorosabbanlazábban összekapcsolódó telepuléscsoportok fejlődésével lehet számolni. Az Alfơld területén lényegében ez - vagyis a telepúléscsoportok kialakulása, fejlödése jeleníti meg a telepưlésrendszer strukturális változását, átalakulását a jövőben is. A szuburbánus fejlödés lesz a strukturális átalakulás "terméke" és hordozója ezeken a területeken, szemben az ország más térségeire jellemző - "klasszikus" értelemben vett - agglomerálódással. Lényegében ez a fejlődés az egykori sajátos mezővárostanya jellegú kapcsolatrendszerre jellemző, az új kihívásokhoz, a társadalmigazdasági fejlödés új feitételeihez alkalmazkodó kifejeződésként értelmezhetó és fogható fel. A Kecskemét, Szeged, Debrecen, Nyíregyháza és más alföldi középvárosok térségeiben a nyolcvanas évektől megfigyelhető településfejlödési folyamatok beható vizsgálata erre enged következtetni. Az érintett lakosság kettős kötődése - a munkahely, a különféle jellegủ és szintü ellátási intézmények és az általuk nyújtott szolgáltatások a városhoz, a létfenntartás feltételei (a táplálékok elöteremtése) - közvetlenưl a szuburbán környezethez kapcsolja, ahhoz formálja az alapvetően megújuló város-falu, város-tanya kapcsolatok jellegét, irányát és tartalmát. A sok új kisváros megjelenése - pontosabban a községek várossá nyilvánítása - a telepulésrendszer fơldrajzi térkéképén tagolja a nagyobb városok vonzásterét, differenciálja a telepulésközi kapcsolatokat, a hagyományos települési szerkezetet átformálja, modernizálja, alkalmassá teszi az új kihívások várható követelményeihez.

Feltételezhetó következtetés, hogy az Alfơld térségének fơldrajzi adottságai, a telepulésszerkezet történelmileg kialakult sajátosságai, a mezőgazdasági termelés markánsabban érvényesülö szerepe, a telepưlésrendszer strukturális átalakulásának - 
az ország dunántúli és északi térségeihez képest - eltérő jelleget adnak. Úgy is fogalmazhatunk, hogy míg az ország nyugati és északi térségeiben térben koncentráltabban megjelenó településstruktúrák határozzák meg a településrendszer átalakulását, jövőbeni fejlődését, addig az Alfơld síkvidéki jellegéből adódóan, a telepúlések funkcionális egymásra utaltságából, kapcsolataiból kővetkezó strukturális átalakulás "felolvad", fơldrajzilag szétterültebb lesz. Az elöbbi térségekhez markánsabban kötődhetnek/kőtődnek a települések egymáshoz, az utóbbiakban lazább jellegünek tetsző kapcsolatok szőtte háló határozza meg a településrendszer strukturális fejlödésének jövőbeni pályáját. Ez a körülmény a települési önkormányzatok lehetséges együttmüködésének is eltérö, legalábbis lényegesebben eltérő keretet szab. Ez a legszembetünöbben a telepulések infrastruktúra fejlesztésére irányuló akcióiban nyilvánulhat meg: a vonalas infrastruktúra települések közötti összehangolt fejlesztését, ha nem is fékezi, de lényegesen mérsékelheti (pl. kơzmüves vízellátás, szennyvízelvezetés vonatkozásában). Ez a közintézmény hálózat fejlesztését illetően is megnyilvánulhat (a települések közötti nagyobb távolságok, a településrend ritkább szemszerkezete csőkkentheti több telepưlés ilyen irányú érdekeltségét az összehangolt fejlesztési akciókban a helyszíni tapasztalatok szerint).

\section{A fơközlekedési vonalak szerepe a településrendszer fejlődésében, szerkezetének átalakulásában}

A közlekedési - különösen a fơközlekedési - kapcsolatoknak, az azokat közvetítö, fogadó vonalaknak mindenkor meghatározó szerepe volt a települések életében, fejlődésében. A települések - különősen a városok - fejlődésének több ezer éves folyamata ezt mutatja.

A kőzlekedési vonalak és az azokon lebonyolódó forgalom szerepe, jelentősége különösen megnbtt az utóbbi évtizedekben. Meghatározó mértékben annak nyomán és következményeként, hogy a közlekedési kapcsolatok, az általuk gerjesztett forgalom a vasútról a kőzutakra - autópályákra, gyorsforgalmú útvonalakra terelödött át. Igaz, a gyors müszaki fejlödés eredményeként a fejlett országokban az elmúlt évtizedekben a vasút megörizte korábbi szerepét a települések közőtti kapcsolatok közvetítésében, fogadásában, s ennek nyomán mérsékelte a kőzutakon bonyolódó forgalom nagyságát.

A közlekedési vonalakon lebonyolódó forgalom nagysága, jellege, intenzitása meghatározó tényezöként érvényesül a telepuilésrendszer szerkezetének változásában, strukturális átalakulásában (mint arra korábban utaltunk). Az agglomerációk, agglomerálódó térségek, városrégiók kialakulása, fejlődése a világ különbözö országaiban, f́gy hazánkban is azt mutatja, hogy ebben a folyamatban elsődleges a közlekedési vonalak szerepe, a kőzlekedési infrastruktúra fejlettsége.

A településstruktúrák szerkezetének vizsgálata arra hivja fel a figyelmet, hogy a közlekedés vonalai - elsősorban és döntően a közutak - ösztönzik, elösegítik a telepulések teruleti összefonódását, összefüggő településtestek kialakulását és fejlődését. $\mathrm{Az}$ autópályák, autóutak kiépưlését kővetően szembetủnő, hogy azok közvetlen kőzelében, szomszédságában építési tevékenység - elsösorban lakóház építkezések - bontakozott/bontakozik ki. A hazánkban eddig megépultt autópályák 
mentén, közelében - mint például az M1, M7 autópályák - kiulönösen a fơváros szomszédságában, gyarapodó kiterjedésü épitési területeket figyelhetünk meg. A rendszerváltás óta eltelt idószak tapasztalatai azt jelzik, hogy ez a folyamat felerősődött. Nemcsak a lakásépítés akciótertiletei "vonzódnak" a fỏ közlekedési vonalak mellé, annak közelébe, hanem az ủj zöldmezős beruházások mind nagyobb része is prioritást ad a telephely választás során az ilyen jellegủ elhelyezkedésnek. A nagy/nagyobb telepulésstruktúrák térségeiben gyorsabb ez a folyamat, szembetünỏ a fó kőzlekedési vonalak mentén egykor szabad területek besürủsödése, lakóépületekkel, idegenforgalmi-vendéglátó létesítményekkel, bevásárló központokkal, sőt ipari, termeló, összeszerelö, illetve forgalmazási-raktározási célokat szolgáló létesítményekkel.

Ez a folyamat feltartóztathatatlannak tünik, tartós tendenciaként érvényesül. A jármúállomány nagyarányú növekedése kiváltotta tetemes jármüforgalom - a rendszerváltás előtti időszakhoz képest - kényszerítő erővel hat a kőzúthálózat modernizálására, fejlesztésére (autópálya hálózat továbbépítése, a fóközlekedési utak felújítása). Ezek az akciók következményeikben a kialakult településstruktúrák további fỏldrajzi kiterjeszkedését, új struktúrák kialakulását, fejlödését ösztőnőzhetik. Ugyanakkor a településrendszer strukturális átalakulásának egyik dinamizáló tényezőjeként is tekinthetjük a fö közlekedési útvonalakat. Mint említettuk, vonzás gyakorolnak a nyomvonalak által érintett térségekben a népesség lakásépítési szándékaira, a különféle vállalkozások (ipari, raktározási, nagykereskedelmi, idegenforgalmi stb.) zöldmezós beruházásainak telephely választására. Ily módon a fơ közlekedési útvonalak mentén kínálkozó építési lehetőségek tơbbirányú hasznosítása révén új telepủlési tengelyek, struktúrák jelennek/jelenhetnek meg a hazai településrendszerben is.

Ezek hatása a telepủlésrendszer fejlödését, átalakulását kettős értelemben befolyásolja. Egyrészt ósszehozza az ország egyes térségeiben viszonylag egymás közeli, fơldrajzi szomszédságában kialakult településstruktúrákat. Felgyorsíthatja fejlödésüket, s ennek hatásaként nagyobb térségek települési viszonyainak átrendezódését eredményezheti. Ilyen jellegủ fejlődéssel a korábban tárgyal budapesti térségben, és Észak-Dunántúl ơvezetében számolhatunk: ebben a folyamatban az Ml-es autópálya vonzó hatása, terület- és telepủlésfejlesztési kơvetkezményei érvényesuilhetnek. A fejlódés hasonló helyzet kialakulását eredményezheti az M7-es autópálya vonzásővezetében, tekintettel a balatoni térség agglomeráltságának elért intenziv jellegére, Székesfehérvár és a Velencei-tó kőrül fekvő településcsoport funkcionális kapcsolataira és az agglomerálódás kibontakozó tendenciáira. Valószínủsíthető az M3-as autópálya, illetve tervezett gyorsforgalmi autóútkénti folytatása nyomán kialakuló vonzásövezet településstruktúra átalakító hatása, az érintett térségben kialakult/kialakuló telepủléscsoportok, a miskolci agglomeráció kőzőtti terủleti ősszefonódásra, az ország északi térségében jelentős földrajzi kiterjeszkedésü területen a települési viszonyok - hosszú folyamatot feltételező - átstrukturálódására. Az M5-ős autópálya mentén hasonló folyamatokkal számolhatunk. Az előbbi fejezetben az Alföld térségével kapcsolatosan említett strukturális változások egyik markáns tényezője, hordozója lehet a fóközlekedési kapcsolatokból kínálkozó lehetőségek hasznosítása. Különősen Szeged, illetve Kecskemét térségében valószínüisithetők - az ország gazdaságának remélt 
dinamikus/dinamikusabb fejlödése nyomán és eredményeként - különböző irányú és jellegü átrendezödések a térszerkezetben és a települési viszonyokban. Szinte minden, nagy forgalmat lebonyolító föforgalmú útvonal mentén várhatók hosszabb, nagyobb távon strukturális változások a terület-felhasználásban, a térszerkezetben, a népesség településrendjében, területi elhelyezkedésében (pl. az északkeletmagyarországi térségból Kárpát-Ukrajna, az Alföld keleti térségéböl Erdély, Románia felé irányuló fớközlekedési útvonalak mentén, illetve vonzáskörzetében stb.).

A fơkőzlekedési útvonalak, az azokon lebonyolódó személy- és teherforgalom fontos ösztönzö tényezöje lehet a határmenti térségek felzárkóztatásának, aktiv bekapcsolódásának a két, vagy többoldalú nemzetkőzi gazdasági kapcsolatck, majd megfelelö feltételek esetén az országok közötti dinamikusabb területi munkamegosztásba, regionális együttmükődésbe. Ezek a vonalak, mintegy csápokként összehozhatják, összekapcsolhatják a határmenti térségek nagyobb városait, regionális centrumait, $\mathrm{s}$ azok körül kialakult/kialakuló településegyütteseket, struktúrákat. Leginkább erre Észak-Dunántúl térségében Gyớr-Pozsony, Györ-Bécs irányában nyilhat lehetőség a közvetlen gazdaságikereskedelmi kapcsolatok vonatkozásában. Ilyen jellegü kapcsolatok alakulhatnak ki - a teljesség igénye nélkül említve - Szombathely és Burgenland középsó régiójának települései, Nagykanizsa és a horvátországi Károlyváros, illetve Zágráb, Pécs és Eszék, Szeged és Szabadka, Békéscsaba és Arad, Debrecen és Szatmárnémeti között, illetve Nyíregyháza-Záhony felöl Ungvár irányába. Természetesen ez ma még távolabbi remények tartománya. A föközlekedési vonalak ösztönözte településfejlödési, strukturális átalakulási folyamatok - objektív jellegükből következöen - ösztönözheti kezeket - a jelenleg mér teoretikus megfontolásnak tünö - kapcsolatokat.

A nyugat-európai országok határmenti térségeiben az elmúlt másfél-két évtizedben végbement településfejlödési folyamatok, településrendszerek strukturális átalakulásának példái tanúsítják a szoros/szorosabb gazdasági, kereskedelmi és egyéb jellegú kapcsolatok intenzív fejlődését, a regionális együttmükődést, a határmenti térségek korábban meglévő el-, illetve lemaradásának jelentós mérséklödését, egykoron perifériális helyzetükbőll következett hátrányok viszonylag gyorsan végbement felszámolódását (pl. Basel térségében, a Rajna-vőlgyében, Svájc és Franciaország között, Dánia és az északnémet területek érintkezésének régiójában és sok helyuitt máshol Nyugat-Európában).

\section{A településstruktúrák szerepe az ország településrendszerében}

Jelen tanulmány szerzőjének először a hetvenes évek végén, a nyolcvanas évek elején - az akkor müködött Építésügyi- és Városfejlesztési Minisztérium több éves jelentös anyagi támogatása alapján - nyílt lehetősége a hazai településrendszer strukturális változását megjelenítö folyamatok és hatásuk nyomán kialakult településstruktúrák vizsgálatára és értékelésére. Ezekben az években OTKA pályázaton nyert kutatások keretében vizsgálja újra a témát, tekintettel az első vizsgálatok óta eltelt időszak alatt - a nyolcvanas években és a kilencvenes évek elsö felében - végbement változásokra. 
A Központi Statisztikai Hivatal a nyolcvanas évek közepétől rendszeresen publikál adatokat a településstruktúrák helyzetéröl, alapul véve a szerző korábbi kutatásainak eredményeit. A Hivatal által a Területi Statisztikai Évkönyvben 1996-ban közzétett, 1995-re vonatkozó adatok szemléltetően tanúsítják a telepưlésstruktúrák helyzetét, szerepét és jelentőségét a mai magyarországi telepưlésrendszerben. Tanulmányunk befejezéseként idézünk ezekből az adatokból, illetve azok alapján végzett számításaink eredményeit mutatjuk be.

1995-ben a településstruktúrákban 6,3 millió ember, az ország népességének 61\%-a élt, Budapest nélkül 4,4 millió. Ez az egyetlen adat önmagában is jelzi, hogy az ország népességszámának terủleti koncentrálódásában milyen meghatározó szerepe van a telepủlésstruktúráknak. Az ország lakásállományának 61,6\%-a itt található.

A telepưlésstruktúrákban élő népesség infrastrukturális ellátottsági viszonyai kedvezóbbek, illetve valamelyest kedvezóbbek az ország egészére vonatkozó mutatóknál. A vezetékes gázt fogyasztó háztartások ezer lakosra jutó száma a településstruktúrákban (ősszességúkben) 282, az ország egészét illetően 229. A kỏzủzemi vízhálózatba bekapcsolt lakások aránya $87,5 \%$ a telepúlésstruktúrákban, $78,9 \%$ országosan. A közcsatorna hálózatba bekapcsolt lakások aránya $63,3 \%$, illetve 44,2\%. Egy háziorvosra és házi gyermekorvosra 1.526 lakos jut a telepủlésstruktúrákban, 1.568 országosan. A mükődő kórházi ágyak 10000 lakosra jutó száma 121, illetve 91 .

Még markánsabban kirajzolódik a telepulésstruktúrák jelentősége, ha a vállalkozásokban betöltỏtt szerepüket, vagy jelenleg az iparban alkalmazásban állók számát vizsgáljuk. A vizsgálatunk alapjául szolgáló statisztikai megfigyelések adatai alapján - a megfigyelt időpontban - a jogi személyiségü vállalkozások száma országosan 116.928 volt, kőzülük 98.037 a településstruktúrákban múködött (Budapesten a számuik 52.539 volt). A jogi személyiség nélküli vállalkozások száma országosan 929.155 volt, ebből a településstruktúrákban mủködők száma 695.326 volt (Budapesten a vonatkozó időpontban 273.519 jogi személyiség nélküli vállalkozás mükődött). A jogi személyiség nélküli vállalkozásokból egyéni vállalkozás volt összesen 791.271, ebból a településstruktúrákban 527.422 mủkỏdött, Budapesten pedig 217.193 (az ország összes egyéni vállalkozásainak közel negyede - a statisztikai megfigyelések szerint). 1995-ben az országban 723.816 fó állt alkalmazásban az iparban, a településstruktúrákban 503.754 fö, míg Budapesten 109.277 fonnek biztosított az ipar munkaalkalmat.

Az utóbbi adatsor kivételével a többi, fentiekben bemutatott adatokat illetóen meghatározó, vagy jelentős Budapest szerepe: nemcsak az ország egészéhez viszonyítottan, hanem a telepúlésstruktúrákon belül is. Ennek ellenére az adatok alapján szemléletesen nyomon követhetó a telepullésstruktúrák vitathatatlan szerepe, jelentösége a mai magyarországi településrendszerben. A KSH által publikált adatok - a tanulmány szerzöjétöl némileg eltéröen - 646 várost, illetve községet sorolnak a településstruktúrák közé 2.749 város, illetve kỏzség a településstruktúrákon kívuil helyezkedik el). 


\section{Jegyzetek}

1 Jelen tanulmány a T $22 / 99$ sz. OTKA pályázat keretében végzett kutatások alapján készullt.

\section{Irodalom}

Csatári Bálint (1995) Az Alfôld helyzete és perspektívái. Békéscsaba

Erlich É. - Révész G. - Tamási P. (1994) Kelet-Kozép-Európa - honnan, hova? Akadémiai Kiadó, Budapest

Enyedi Gyorgy (1994) Budapest az európai nagyvárosi rendszerben. Európai Szemle V. évf. 2. sz.

Enyedi György (1996) Regionális folyamatok Magyarországon. Ember-telepulés-régió, Budapest

Enyedi György (1997) Városok a közép-európai átmenetben. Társadalmi Szemle, 8-9. sz. :42-56. o.

Erdősi Ferenc (1991) Kommunikáció és térszerkezet. Akadémiai Kiadó, Budapest

Kőszegfalvi György (1984) A magyarországi telepulésrendszer strukturális változása. Teruletfejlesztési

Közlemények 13., Budapest

Kőszegfalvi György (1993) A főváros fejlesztésének új feltételei. Telepulésfejlesztés 3. sz.

Kőszegfalvi Gyorgy (1995) Budapest szerepe, jelentősége az ország társadalmi-gazdasági életében. Kézirat, KSH Budapesti Igazgatósága, Budapest

Kőszegfalvi Gyơrgy (1995) Rendszerváltás és telepullések. Habilitációs elỏadás kézirata, JPTE, Pécs

Kőszegfalvi Gyorgy (1995) Meddig ér a budapesti agglomeráció? Kézirat, KSH Budapesti Igazgatósága, Budapest

Kőszegfalvi György (1997) Hazánk kőzépvárosai. JPTE Közleményei, Pécs

Mészáros Rezsó (1994) A telepulés térbelisége. JATEPress, Szeged

Perczel Gy. - Tóth J. (szerk.) (1996): Magyarország társadalmi-gazdasági foldrajza. Eotvơs Kiadó, Budapest

Rechnitzer János (1993) Szétszakadás, vagy felzárkózás. MTA RKK, Györ

Szabó Gábor (szerk.) (1997) Város és vonzáskerzete. Önekor•kép Kiadó, Budapest

Tóth József (1988) Urbanizáció az Alfoldón. Akadémiai Kiadó, Budapest

Tóth József (1993) Nagyvárosok a magyar telepulésrendszerben. Comitatus IIl. évf. 7-8. sz. 40-54. o. 